\title{
Dorota Łoвos-KotowsKa
}

\section{Nabywanie udziałów i akcji przez cudzoziemców w spółkach będących właścicielami nieruchomości rolnych}

1. Polska posiada znaczne zasoby użytków rolnych $(15,5 \mathrm{mln}$ ha), które stanowią 49\% powierzchni kraju. Użytki rolne w Polsce cechuje atrakcyjne położenie w centrum Europy, cenne walory krajobrazowo-przyrodnicze, w tym wysoki stopień bioróżnorodności, stosunkowo niski stopień degradacji gleb spowodowany niezbyt intensywną gospodarką rolną, niska cena w porównaniu z państwami Europy Zachodniej. Te cechy powodują, że polskie nieruchomości rolne mogą stanowić interesującą ofertę dla zagranicznych nabywców. Nadto należy wziąć pod uwagę, że Polska jako członek UE jest w pełni włączona w procesy globalne, a problematyka transgranicznego obrotu nieruchomościami rolnymi nabiera znaczenia z uwagi na możliwe skutki procesu przejmowania faktycznej kontroli nad obszarami gruntów rolnych. Jako szczególnie istotne wymienia się ograniczenie możliwości prowadzenia gospodarstwa rolnego przez lokalnych producentów rolnych. Pozostałe zagrożenia to: ograniczenie możliwości korzystania z zasobów naturalnych, degradacja środowiska naturalnego, zmiany przeznaczenia gruntów, zmniejszenie bezpieczeństwa żywnościowego państwa. Procesy te mają istotne znaczenie, jeżeli skala zjawiska jest znacząca, a transgraniczne nabycie nieruchomości rolnych dotyczy znacznych areałów gruntów lub następuje koncentracja gruntów w rękach stosunkowo niewielkiej liczby przedsiębiorców. ${ }^{1}$ Także w mniejszym zakresie transgraniczny obrót nieruchomości rolnymi może stanowić pewne

${ }^{1}$ Szerzej na temat procesu określanego w doktrynie jako „land grabbing” - por. R. Pastuszko, Land grabbing. Podstawowe zagadnienia prawne, „Studia Iuridica Lublinensia” 2017, vol. XXVI, nr 1, s. 147 i n. Autor zauważa, że zjawisko to występuje przede wszystkim poza Europą, jednak w obecnej dekadzie obszary miejsca inwestycji uległy znacznemu rozszerzeniu i dotyczą także państw europejskich. 
zagrożenie, które zostało dostrzeżone przez Europejski Komitet Ekonomiczno-Społeczny w opinii z dnia 22.01.2015 r. w sprawie „Masowy wykup gruntów rolnych - dzwonek alarmowy dla Europy i zagrożenie dla rolnictwa ekologicznego". ${ }^{2}$ Autorzy opinii zauważają, że obok nabycia gruntów rolnych, przejęcie kontroli następuje z zastosowaniem prawnych instrumentów nabycia przedsiębiorstw mających tytuł prawny do nieruchomości rolnych lub udziałów lub akcji w spółkach, które są właścicielami nieruchomości rolnych.

W odpowiedzi na te zagrożenia Polska, podobnie jak niektóre inne państwa UE, ograniczyła swobodę obrotu nieruchomościami i wprowadziła kontrolę tego obrotu zarówno przy wykorzystaniu instrumentów ze sfery prawa prywatnego, jak i prawa publicznego. I choć wprowadzenie kontroli obrotu uznać należy za zjawisko w pełni pozytywne, ocenie poddać należy stopień ingerencji polskiego ustawodawcy w obrót nieruchomościami oraz poziom legislacji w tym zakresie. $Z$ uwagi na szeroki zakres problematyki, w niniejszym opracowaniu została ona ograniczona do kontroli nabywania przez cudzoziemców udziałów i akcji w spółkach będących właścicielami lub użytkownikami wieczystymi nieruchomości rolnych.

2. W sferze publicznoprawnej nabywanie przez cudzoziemców prawa własności i prawa użytkowania wieczystego nieruchomości położonych w Polsce jest przedmiotem szczególnej regulacji prawnej wielokrotnie nowelizowanej ustawy z dnia 24.03.1920 r. o nabywaniu nieruchomości przez cudzoziemców, dalej zwana u.n.n.c. ${ }^{3}$. Już na wstępie zauważyć należy, że obrót polskimi nieruchomościami na rzecz podmiotów zagranicznych z Europejskiego Obszaru Gospodarczego i Konfederacji Szwajcarskiej uległ znacznej liberalizacji będącej konsekwencją akcesji Polski do UE. Znalazło to wyraz w zał. XII do Traktatu Akcesyjnego z 16.04.2003 r. ${ }^{4}$ Z chwilą przystąpienia Polski do UE, cudzoziemcy z EOG i Szwajcarii nie muszą legitymować się zezwoleniem na nabycie nieruchomości oraz nabycie lub objęcie udziałów lub akcji w spółkach będących właścicielami lub użytkownikami wieczystymi nieruchomości położonych w Polsce. Wyjątkiem było nabycie nieruchomości rolnych i leśnych przez okres przejściowy dwunastu lat, który upłynął 30.04.2016 r. ${ }^{5}$ Wymóg

2 2015/C 242/03.

3 T.j. Dz.U z 2017 r., poz. 2278.

4 Dz.U. nr 90, poz. 864 z zał.

${ }^{5}$ Od 1 maja 2004 r. nie jest wymagane uzyskanie zezwolenia przez cudzoziemców będących obywatelami Europejskiego Obszaru Gospodarczego lub Konfederacji Szwajcarskiej, z wyjątkiem nabycia nieruchomości rolnych i leśnych. Wyjątek ten obowiązuje w 12-letnim okresie przejściowym, od dnia przystąpienia Polski do UE do dnia 30.04.2016 r. i nie dotyczy nabycia nieruchomości rolnych położonych: w woj.: dolnośląskim, kujawsko-pomorskim, lubuskim, opolskim, pomorskim, 
uzyskania zezwolenia przez wskazane podmioty na nabycie nieruchomości rolnych i leśnych obowiązujący w okresie przejściowym przyjęty był w drodze wyjątku od obowiązującej w państwach członkowskich EOG zasady swobodnego przepływu kapitału, z której wynika też swoboda nabywania nieruchomości, udziałów i akcji. Zatem wyjątków tych nie należy interpretować rozszerzająco, a ograniczenia nie obejmowały nabywania lub obejmowania przez wskazane podmioty udziałów lub akcji w spółkach będących właścicielami lub użytkownikami wieczystymi nieruchomości położonych w Polsce, także gdy były to nieruchomości rolne lub leśne. Swoboda nabywania i obejmowania udziałów i akcji w takich spółkach przez podmioty z państw EOG i Szwajcarii obowiązywała więc od chwili wejścia Polski do UE, niezależnie od rodzaju nieruchomości.

W efekcie przyjętych rozwiązań, u.n.n.c. dzieli cudzoziemców na dwie kategorie: cudzoziemcy z Europejskiego Obszaru Gospodarczego i Konfederacji Szwajcarskiej oraz cudzoziemcy z innych państw ${ }^{6}$. W stosunku do cudzoziemców z poza EOG i Szwajcarii, obowiązuje zasada wyrażona w art. 1 ustawy, która stanowi, że nabycie nieruchomości przez cudzoziemca wymaga zezwolenia wydanego w drodze decyzji administracyjnej, z pewnymi wyjątkami przewidzianymi w art. 8 ust. 1 ustawy. Natomiast w odniesieniu do obywateli i przedsiębiorców z EOG i Szwajcarii obowiązuje odrębna reguła, ustanowiona w art. 8 ust. 2 ustawy. W stosunku do tej kategorii cudzoziemców nie jest wymagane uzyskanie zezwolenia na nabycie nieruchomości, z pewnymi wyjątkami.

Zezwolenie na nabywanie nieruchomości wydaje w Polsce minister właściwy do spraw wewnętrznych, jeśli sprzeciwu nie wniesie Minister Obrony Narodowej, a w przypadku nieruchomości rolnych, jeżeli sprzeciwu nie wniesie minister właściwy do spraw rozwoju wsi. Przepisy powołanej ustawy mają zastosowanie do nabycia własności nieruchomości, a także nabycia użytkowania wieczystego na podstawie każdego zdarzenia prawnego. Ustawa nie ma natomiast zastosowania do nabycia ograniczonych praw rzeczowych (użytkowanie, służebności) lub obligacyjnych (dzierżawa). Zezwolenie jest wydawane na wniosek cudzoziemca jeżeli: nabycie nieruchomości nie spowoduje zagroże-

warmińsko-mazurskim, wielkopolskim, zachodniopomorskim - po upływie 7 lat od dnia zawarcia umowy dzierżawy z datą pewną, jeżeli przez ten czas osobiście prowadzili na tej nieruchomości działalność rolniczą oraz legalnie zamieszkiwali na terytorium RP; natomiast w woj.: lubelskim, łódzkim, małopolskim, podkarpackim, podlaskim, śląskim, świętokrzyskim - po upływie 3 lat od dnia zawarcia umowy dzierżawy z datą pewną, jeżeli przez ten czas osobiście prowadzili na tej nieruchomości działalność rolniczą oraz legalnie zamieszkiwali na terytorium RP.

${ }^{6}$ Por. J.J. Skoczylas, Cywilnoprawny obrót nieruchomościami przez cudzoziemców, Warszawa 2008. 
nia obronności, bezpieczeństwa państwa lub porządku publicznego, a także nie sprzeciwią się temu względy polityki społecznej i zdrowia społeczeństwa oraz gdy cudzoziemiec wykaże, że zachodzą okoliczności potwierdzające jego więzi z RP.

Zasady nabywania nieruchomości przez cudzoziemców znajdują zastosowanie także do „nabycia nieruchomości” poprzez nabycie lub objęcie przez cudzoziemca udziałów (akcji) w spółce handlowej z siedzibą na terytorium RP, która jest właścicielem lub użytkownikiem wieczystym nieruchomości (gruntowej, budynkowej lub lokalowej), jeżeli spółka ta stanie się spółką kontrolowaną (cudzoziemiec uzyska powyżej 50\% głosów na jej zgromadzeniu wspólników lub na walnym zgromadzeniu lub pozycję dominującą w rozumieniu przepisów polskiego Kodeksu Spółek Handlowych) albo jeżeli spółka ta jest już kontrolowana, a udziały lub akcje nabywa lub obejmuje nowy inwestor strategiczny, który jest cudzoziemcem (art. 3a ust. 1 i 2 u.n.n.c.). Oznacza to, że wprawdzie nabycie lub objecie udziałów (akcji) w takiej spółce nie wymaga uzyskania zezwolenia przez cudzoziemców z siedzibą w EOG lub Konfederacji Szwajcarskiej (art. 8 ust. 2 u.n.n.c.), ale cudzoziemcy spoza tego obszaru zasadniczo zobowiązani będą do uzyskania zezwolenia (art. 3a ust. 1 i 2 u.n.n.c.). Hipotezą art. 3e u.n.n.c. są zatem objęte spółki prawa handlowego: spółka z ograniczoną odpowiedzialnością i spółka akcyjna, ale także spółka komandytowo-akcyjna. Poza zakresem przedmiotowym powołanego przepisu pozostają natomiast spółki z siedzibą na terytorium naszego kraju, które są wyłącznie właścicielami nieruchomości położonych za granicą.

Obowiązek uzyskania zezwolenia na nabycie lub objęcie udziałów lub akcji nie dotyczy przypadków, gdy akcje spółki są dopuszczone do obrotu na rynku regulowanym, albo spółka jest właścicielem lub użytkownikiem wieczystym nieruchomości wyłączonej spod obowiązku uzyskania zezwolenia. Nie ma także zastosowania do udziałów i akcji w spółkach tworzących struktury holdingowe. $\mathrm{Z}$ przepisu art. 3e ustawy nie można bowiem wywieść i egzekwować ograniczeń związanych z udzielaniem zezwoleń na nabywanie przez cudzoziemców akcji spółek wiodących (niezależnie od rozmiarów uczestnictwa) niebędących właścicielami lub wieczystymi użytkownikami nieruchomości w sytuacji, gdy wskazane tytuły prawne do nieruchomości mają spółki córki. ${ }^{7}$

Co istotne, u.n.n.c. w art. 6 przewiduje sankcję bezwzględnej nieważności w przypadku nabycia nieruchomości i nabycia lub objęcia udziałów lub akcji wbrew przepisom ustawy.

7 Zdaniem NSA tego rodzaju ograniczenie mogłaby zasadnie zostać odczytane jako wyraz dążenia do zapewnienia kontroli administracyjnej szerszego łańcucha powiązań kapitałowych, bez właściwego oparcia w prawie, uchwała (7) NSA z 24.09.2001 r., OPS 10/01, ONSA 2002/1/10, Prok.i Pr.-wkł. 2002/1/49 z glosą aprobującą J. J. Skoczylasa. 
W 2017 r. cudzoziemcy uzyskali 19 zezwoleń na nabycie udziałów i akcji w spółkach będących właścicielami lub użytkownikami wieczystymi nieruchomości położonych w Polsce o łącznej powierzchni 88,09 ha. W tym samym okresie wydano 4 zezwolenia na nabycie udziałów lub akcji w spółkach będących właścicielami lub użytkownikami wieczystymi nieruchomości rolnych. Przy ocenie prezentowanych danych należy jednak mieć na względzie, że mogą to być dane niekompletne, na co wpływa zjwisko nieformalnego nabywania nieruchomości rolnych. W Polsce istotny problem stanowi bowiem obrót nieformalny, a właściwie praktyka nabywania nieruchomości rolnych przez osoby podstawione, działające na rzecz dużych podmiotów, które formalnie nie mogą w Polsce nabyć nieruchomości. Gdy chodzi o nabycie lub objęcie w ten sposób udziałów i akcji przez cudzoziemców z EOG i Szwajcarii - byli to głównie cudzoziemcy z Holandii, Danii i Luksemburga. ${ }^{8}$ Nadto zauważyć należy, że dane Ministra Spraw Wewnętrznych mogą być istotnie zaniżone, gdyż spółki kontrolowane przez obcokrajowców nie muszą składać informacji o posiadanych gruntach. Podstawowe znaczenie może mieć także nowelizacja ustawy z dnia 11.04.2003 r. o kształtowaniu ustroju rolnego, dalej zwana u.k.u.r. ${ }^{9}$.

3. Wskazać należy, iż w sferze prywatnoprawnej obrót udziałami i akcjami na rzecz cudzoziemców następuje na podstawie przepisów k.s.h. ${ }^{10}$ oraz aktów wewnętrznych spółki, a także - zgodnie z art. 1a ust. 6 u.n.n.c. - do nabywania nieruchomości przez cudzoziemców zastosowanie mają przepisy ustawy o kształtowaniu ustroju rolnego. Ustawa ta przewidywała już w pierwotnym brzmieniu istotne ograniczenia $\mathrm{w}$ obrocie nieruchomościami rolnymi polegające na przyznaniu dzierżawcy oraz Agencji Nieruchomości Rolnych prawa pierwokupu nieruchomości rolnych (art. 3 u.k.u.r) oraz prawa nabycia przez Agencję Nieruchomości Rolnych (art. 4 u.k.u.r.). Ustawa z dnia 14.04.2016 r. o wstrzymaniu sprzedaży nieruchomości Zasobu Własności Rolnej Skarbu Państwa oraz o zmianie niektórych ustaw ${ }^{11}$, która zmieniła zasadniczo przepisy u.k.u.r., obrót ten jeszcze ograniczyła. W szczególności ustawodawca wprowadził kontrolę obrotu udziałami i akcjami w spółkach prawa handlowego będących właścicielami nieruchomości. Tym samym nie tylko obrót nieruchomościami rolnymi i gospodarstwami rolnymi jest przedmiotem ingerencji

${ }^{8}$ Dane po kontroli NIK dotyczącej sprzedaży ziemi należącej do Skarbu Państwa w latach 2011-2013 (do kwietnia) w trzech oddziałach Agencji Nieruchomości Rolnych: w Szczecinie, Warszawie i Wrocławiu.

9 T.j. Dz.U. z 2017 r., poz. 2196 ze zm.

${ }^{10}$ Ustawa z dnia 15.09.2000 r. Kodeks spółek handlowych, t.j. Dz.U. z 2017 r., poz. 1577 ze zm.

${ }^{11}$ Dz.U. z 2016 r., poz. 585. 
Krajowego Ośrodka Wsparcia Rolnictwa, ale działaniu ustawy poddano także obrót prawami udziałowymi. ${ }^{12}$ Regulacje te dotyczą także cudzoziemców nabywających udziały i akcje w spółkach będących właścicielami nieruchomości rolnych.

Przepisy u.k.u.r. nie różnicują sytuacji prawnej spółek w zależności od tego czy prowadzą działalność rolniczą, czy tylko są właścicielami nieruchomości rolnych. Bez znaczenia jest także liczba i wartość zbywanych udziałów (akcji) oraz czy nieruchomość rolna stanowi istotny czy marginalny składnik w majątku spółki. Dla zastosowania ograniczenia w zbyciu udziałów (akcji) znaczenie ma tytuł prawny własności nieruchomości rolnej ${ }^{13}$. Przyjęta regulacja nie współgra zatem z intencją ustawodawcy, którą jest ochrona ziemi rolnej przed jej spekulacyjnym nabywaniem przez podmioty zagraniczne, nie gwarantujące zgodnego $\mathrm{z}$ interesem społecznym wykorzystania nabytej ziemi na cele rolnicze ${ }^{14}$. Faktyczny skutek wprowadzonych ograniczeń w obrocie udziałami i akcjami spółek będących właścicielami nieruchomości rolnych jest bowiem inny, a polega na przystąpieniu do spółki podmiotu zewnętrznego, Krajowego Ośrodka Wsparcia Rolnictwa działającego na rzecz Skarbu Państwa, co wpływa bezpośrednio na autonomię spółek. Pozwala bowiem KOWR na realizację praw korporacyjnych, mimo iż nie zawsze jest to równoznaczne z wpływem na decydowanie o losach nieruchomości rolnej ${ }^{15}$.

3.1. Zgodnie $\mathrm{z}$ art. 3a u.k.u.r. nabycie akcji i udziałów w spółkach prawa handlowego, które są właścicielami nieruchomości rolnych następuje z uwzględnieniem prawa pierwokupu Krajowego Ośrodka Wsparcia Rolnictwa działającego na rzecz Skarbu Państwa, a regulacja ta dotyczy także cudzoziemców nabywających udziały lub akcje w takich spółkach. Prawo pierwokupu KOWR dotyczy bowiem spółek prawa handlowego, które posiadają udziały lub akcje, a zatem obu spółek kapitałowych (spółki z ograniczoną odpowiedzialnością i spółki akcyjnej) oraz spółki komandytowo-akcyjnej jako jedynej z katalogu spółek osobowych, która posiada uprawnienie do emisji akcji, jeżeli

${ }_{12}$ Por. Z. Truszkiewicz, Zakres stosowania ustawy o ksztaltowaniu ustroju rolnego po nowelizacji z 2016 r., ,Rejent” 2017, nr 7 (315), s. 101 i n.

${ }_{13}$ Por. A. Jurcewicz, Wplyw ustawy z dnia 14 kwietnia 2016 r. o wstrzymaniu sprzedaży nieruchomości Zasobu Własności Rolnej Skarbu Państwa na ksztattowanie ustroju rolnego - zagadnienia wybrane, SIA tom XV, 2017 r., s. 228; argument ten podnosi także J. Grykiel, Ograniczenia obrotu nieruchomościami rolnymi oraz prawami udziałowymi w spółkach po nowelizacji ustawy o ksztaltowaniu ustroju rolnego, „Monitor Prawniczy” 2016, nr 12, s. 638.

${ }^{14}$ Uzasadnienie do projektu ustawy o wstrzymaniu sprzedaży nieruchomości, s. 2; www. anr.gov.pl.

${ }^{15}$ Zwraca na to uwagę J. Bieluk, Prowadzenie działalności rolniczej przez osoby prawne w: P. Litwiniuk (red.), Kwestia agrarna. Zagadnienia prawne i ekonomiczne, Warszawa 2016, s. 280. 
spółki te są właścicielami (współwłaścicielami) nieruchomości rolnych ${ }^{16}$. Ustawodawca nie wprowadził natomiast ograniczeń w obrocie udziałami (akcjami) spółek, którym przysługuje prawo użytkowania wieczystego (współużytkowania wieczystego) nieruchomości rolnych. Reguła odpowiedniego stosowania przepisów przewidziana $\mathrm{w}$ art. 2c odnosi się bowiem do nabycia użytkowania wieczystego nieruchomości rolnej, zaś art. 3a dotyczy prawa pierwokupu udziałów (akcji), co nie jest tożsame z nabyciem nieruchomości w rozumieniu u.k.u.r., choć pośrednio do tego prowadzi. Gdyby nabycie nieruchomości rolnej rozumieć sensu largo, tj. z uwzględnieniem nabycia udziałów (akcji) w spółkach kapitałowych, art. 3a należałoby uznać za zbędny, tym bardziej, że przy takiej wykładni wyłącznym nabywcą udziałów (akcji) mógłby być tylko rolnik indywidualny. Nie taka była jednak intencja ustawodawcy, co wynika z całokształtu norm u.k.u.r. ${ }^{17}$ Zauważyć jedynie należy, że charakter ograniczeń przewidzianych $\mathrm{w}$ u.n.n.c. nie współgra $\mathrm{z}$ regulacją u.k.u.r. w odniesieniu do tytułu prawnego do gruntu, który podlega kontroli. Ustawa o n.n.c. wprowadza bowiem obowiązek uzyskania zezwolenia na nabycie udziałów lub akcji w spółkach będących właścicielami i użytkownikami wieczystymi nieruchomości w odniesieniu do cudzoziemców z EOG i Szwajcarii, gdy tymczasem u.k.u.r. wprowadza ograniczenia tylko dla spółek będących właścicielami nieruchomości rolnych. Warto natomiast odnotować, że podobnie jak w u.n.n.c., ograniczenia z u.k.u.r. nie dotyczą transakcji pośrednich - obrotu udziałami lub akcjami spółek, będących udziałowcami lub akcjonariuszami spółek, które są właścicielami nieruchomości rolnych.

Pozostałe ustawowo określone wyłączenia prawa pierwokupu KOWR dotyczą akcji dopuszczonych do obrotu zorganizowanego w rozumieniu ustawy z dnia 29.07.2005 r. o obrocie instrumentami finansowymi ${ }^{18}$, zbycia udziałów i akcji na rzecz osoby bliskiej, nabycia udziałów i akcji przez Skarb Państwa oraz zbycia udziałów i akcji na rzecz spółki prawa handlowego, której wyłącznym udziałowcem albo akcjonariuszem jest Skarb Państwa, będącej operatorem systemu przesyłowego albo posiadającej koncesję na przesyłanie paliw ciekłych,

${ }^{16}$ Za przyjęciem, że komentowany przepis dotyczy także spółki komandytowo-akcyjnej, przemawia uprawnienie do emisji akcji oraz stosowanie na podstawie art. $126 \S 1$ pkt 2 k.s.h. przepisów o spółce akcyjnej do zbywania akcji w spółce komandytowo-akcyjnej. Ponadto art. $8 \S 1$ k.s.h. w sposób jednoznaczny stanowi o możliwości nabywania praw, w tym własności nieruchomości przez każdą spółkę osobową, a więc także przez spółkę komandytowo-akcyjną.

${ }_{17}$ Stanowisko takie prezentują m.in. J. Grykiel, Ograniczenia ..., s. 628, J. Bieluk, Ustawa o ksztaltowaniu ustroju rolnego. Komentarz, Warszawa 2016, s. 148, inaczej K. Maj, Zmiany w ustawie o ksztattowaniu ustroju rolnego obowiazujace od dnia 30.04.2016 r., „Krakowski Przegląd Notarialny" 2016, nr 2, s. 94 oraz Z. Truszkiewicz, Zakres stosowania ustawy o ksztattowaniu ustroju rolnego po nowelizacji z 2016 r., „Rejent” 2017, nr 7 (315).

${ }^{18}$ Dz.U. z 2017 r. poz. 1768 ze zm. 
w rozumieniu ustawy z dnia 10 kwietnia 1997 r. - Prawo energetyczne ${ }^{19}$. Ramy objętościowe niniejszego artykułu nie pozwalają na szersze omówienie wskazanych wyłączeń, zauważyć jednak należy, że odmiennie niż to ma miejsce w u.n.n.c., ograniczenia obrotu prawami udziałowymi są wyłączone nie tylko w odniesieniu do akcji dopuszczonych do obrotu na rynku giełdowym, ale i w alternatywnym systemie obrotu ${ }^{20}$.

Zgodnie z art. 3a u.k.u.r., zbywca może zatem zbyć udziały (akcje) cudzoziemcowi jedynie pod warunkiem nieskorzystania przez uprawniony Krajowy Ośrodek z prawa pierwokupu. Prawo pierwokupu dotyczy wyłącznie zbycia udziałów (akcji) w formie umowy sprzedaży, nie ma natomiast zastosowania do objęcia akcji w podwyższonym kapitale zakładowym oraz do sprzedaży poboru akcji. Nabycie i objęcie udziałów (akcji) to dwie różne instytucje prawne. Nabycie ma charakter wtórny i dotyczy istniejących udziałów (akcji), natomiast objęcie udziałów (akcji) ma charakter pierwotny i dotyczy nowoutworzonych udziałów (akcji). Podobne rozróżnienie występuje również w art. 3e ustawy z dnia 24.03.1920 r. o nabywaniu nieruchomości przez cudzoziemców ${ }^{21}$. Wątpliwości budzi także nabycie udziałów (akcji) przez spółkę w celu ich umorzenia. Literalne brzmienia przepisu art. 3a u.k.u.r. uprawnia Krajowy Ośrodek do skorzystania z prawa pierwokupu. Taka wykładnia jest jednak sprzeczna z celami u.k.u.r. Celem zbycia nie jest bowiem zmiana udziałowca (akcjonariusza), a umorzenie ${ }^{22}$. Zbywca udziałów (akcji) zawiera z cudzoziemcem zobowiązującą umowę sprzedaży, pod warunkiem zawieszającym nieskorzystania przez Krajowy Ośrodek z prawa pierwokupu. To na zbywcy ciąży obowiązek zawiadomienia uprawnionego do pierwokupu o treści zawartej umowy. Złożenie zawiadomienia o treści umowy sprzedaży udziałów akcji Krajowemu Ośrodkowi rozpoczyna miesięczny bieg terminu do wykonania prawa pierwokupu (art. $598 \S 2$ k.c.). ${ }^{23}$

19 Dz.U. z 2018 r. poz. 755 ze zm.

${ }^{20}$ Alternatywnym systemem obrotu jest m.in. obrót na NewConnect, natomiast nie stanowi alternatywnego systemu obrotu rynek organizowany przez Narodowy Bank Polski, jak również organy publiczne, którym powierzono zarządzanie długiem publicznym lub które uczestniczą w takim zarządzaniu, w tym lokując środki pochodzące $\mathrm{z}$ tego długu - ustawa z dnia 29.07.2005 r. o obrocie instrumentami finansowymi, Dz.U. z 2017 r. poz. 17.

${ }^{21}$ Podobnie J. Bieluk, Ustawa o ksztaltowaniu ..., s. 152, K. Maj, Zmiany..., s. 94, H. Ciepła, Aspekty prawne obrotu gruntami rolnymi od 30.04.2016 r. na nowych zasadach ustalonych w ustawie z dnia 11.04.2003 r. o ksztattowaniu ustroju rolnego oraz w ustawie z dnia 14.04.2016r. o wstrzymaniu sprzedaży nieruchomości Zasobu Własności Rolnej Skarbu Państwa, „Rejent” 2016, $\mathrm{nr}$ 9, s. 33, P. Blajer, Debata na temat „Obrót nieruchomościami rolnymi i leśnymi w praktyce notarialnej", Warszawa 30.09.-1.10.2016 r., przeciwne stanowisko w tej sprawie prezentowała w trakcie debaty ANR.

${ }^{22}$ Podobnie K. Maj, Zmiany ..., s. 94.

${ }^{23}$ Tak określony termin do wykonania prawa pierwokupu należy przyjąć na podstawie art. 3a ust. 4, który do prawa pierwokupu udziałów (akcji) przez Krajowy Ośrodek nakazuje stosowanie 
Poprzez złożenie oświadczenia przez Krajowy Ośrodek do skutku dochodzi umowa o treści tożsamej z zawartą z osobą trzecią (art. $600 \S 1$ k.c.). Krajowy Ośrodek wysyła zobowiązanemu z prawa pierwokupu oświadczenie o wykonaniu prawa pierwokupu przesyłką poleconą nadaną za potwierdzeniem odbioru w placówce pocztowej operatora pocztowego w rozumieniu ustawy z dnia 23.11.2012 r. - Prawo pocztowe ${ }^{24}$, a następnie publikuje na stronie podmiotowej w Biuletynie Informacji Publicznej Krajowego Ośrodka (art. 3 ust. 4 w zw. $\mathrm{z}$ art. 3 ust. 10 i 11 u.k.u.r.). Oświadczenie Krajowego Ośrodka o wykonaniu prawa pierwokupu nie wymaga zachowania formy aktu notarialnego, a zgodnie z art. 597 \$2 k.c. wystarczające jest zachowanie formy przewidzianej dla sprzedaży udziałów (forma pisemna z podpisem notarialnie poświadczonym) lub akcji (forma pisemna). Uważa się, że zobowiązany zapoznał się z treścią oświadczenia Krajowego Ośrodka o wykonaniu prawa pierwokupu z chwilą jego publikacji na stronie podmiotowej w Biuletynie Informacji Publicznej Krajowego Ośrodka. Oświadczenie staje się zatem skuteczne już z chwilą publikacji w BIP, tj. przed doręczeniem oświadczenia wysłanego pocztą ${ }^{25}$, a nawet niezależnie od tego, czy oświadczenie dojdzie do adresata ${ }^{26}$. Nowelizacja u.k.u.r. zmodyfikowała zatem funkcje BIP, który w założeniach miał służyć wyłącznie udostępnianiu informacji publicznej, nadając publikacji oświadczeń cywilnoprawny skutek w postaci nabycia przez Krajowy Ośrodek udziałów (akcji) spółek. Dostrzec należy jednak różnicę w odniesieniu do chwili nabycia udziałów przez Krajowy Ośrodek oraz akcji, do których przeniesienia praw akcyjnych konieczne jest wydanie dokumentu akcyjnego. W pierwszym przypadku Skarb Państwa, w imieniu którego działa Krajowy Ośrodek, staje się właścicielem udziałów z chwilą publikacji oświadczenia o wykonaniu prawa pierwokupu. W drugim natomiast przypadku, gdy do nabycia konieczne jest przeniesienie posiadania dokumentu akcji, publikacja oświadczenia w BIP powoduje powstanie zobowiązania dotychczasowego akcjonariusza do wydania dokumentu akcji i przeniesienia praw udziałowych w spółce akcyjnej lub komandytowo-akcyjnej ${ }^{27}$. Dopiero, gdy Krajowy Ośrodek nie skorzysta z prawa pierwokupu lub bezskutecznie upłynie termin dla realizacji tego uprawnienia, strony umowy powinny zawrzeć umowę przenoszącą własność udziałów lub

przepisów kodeksu cywilnego dotyczących prawa pierwokupu nieruchomości, tak też J. Grykiel, Ograniczenia..., s. 637 i J. Bieluk, Ustawa o kształtowaniu..., s. 153.

${ }^{24}$ T.j. Dz.U. z 2017 r. poz. 1481 ze zm.

25 J. Bieluk, Ustawa o ksztaltowaniu..., s. 130.

${ }^{26}$ W. Fortuński, M. Kupis, Uwagi do ustawy o ksztaltowaniu ustroju rolnego po nowelizacji, „Nowy Przegląd Notarialny” 2016, nr 2, s. 53.

${ }^{27}$ Tak m.in. J. Bieluk, Ustawa o ksztaltowaniu ..., s. 153-156, M. Komarowska, Nowa funkcja Biuletynu Informacji Publicznej wynikajaca z ustawy o ksztaltowaniu ustroju rolnego, „Studia Iuridica Agraria” 2017, t. XIV, s. 168-169). 
akcji. Odesłanie do przepisów o prawie pierwokupu dotyczących nieruchomości nie wyłącza bowiem stosowania art. 157 § 2 k.c., zgodnie z którym jeżeli umowa zobowiązująca do przeniesienia własności nieruchomości została zawarta pod warunkiem lub z zastrzeżeniem terminu, do przeniesienia własności potrzebne jest dodatkowe porozumienie stron obejmujące ich bezwarunkową zgodę.

Nadmiernym uprzywilejowaniem KOWR jest także wyposażenie tej instytucji w uprawnienie do badania stanu spółki przed nabyciem jej udziałów (akcji), a więc de facto do przeprowadzenia due diligence spółki: przeglądania ksiąg i dokumentów spółki, żądania od spółki informacji dotyczących obciążeń i zobowiązań nieujętych w księgach i dokumentach. ${ }^{28}$ Krajowy Ośrodek ma miesięczny termin zawity na wykonanie prawa pierwokupu, jest to także maksymalny czas na wykonanie uprawnienia do zapoznania się ze stanem prawnym spółki przed złożeniem oświadczenia o wykonaniu prawa pierwokupu. Uprawnienie to dotyczy zapoznania się ze stanem całego majątku spółki w celu prawidłowej wyceny udziałów (akcji), a nie tylko wyceny wartości nieruchomości rolnej. Wadą regulacji jest brak określenia skutków prawnych odmowy udostępnienia ksiąg lub dokumentów albo nieudzielenia informacji. W szczególności odmowa taka nie powoduje przedłużenia terminu na wykonanie prawa pierwokupu. Nadto podkreślić należy, że przepisy u.k.u.r nie przewidują żadnej sankcji za nieudostępnienie ksiąg i dokumentów spółki. $\mathrm{Z}$ drugie strony należy także wziąć pod uwagę, że uprawnienie przewidziane w komentowanym przepisie daje KOWR możliwość zapoznania się ze stanem prawnym spółki zbywającej udziały (akcje) nawet wówczas, gdy nieruchomość rolna stanowi nieistotny, marginalny składnik majątku spółki oraz gdy KOWR nie wykona prawa pierwokupu. Tak szerokie uprawnie KOWR zaburza konkurencję, może powiem prowadzić do uzyskania przewagi rynkowej w sytuacji, gdy instytucja jest wspólnikiem (akcjonariuszem) innej spółki o tym samym przedmiocie działalności.

3.2. Zbycie udziałów (akcji) w drodze innych czynności prawnych, takich jak darowizna, zamiana, datio in solutum oraz innych zdarzeń prawnych, które skutkują nabyciem udziałów lub akcji w spółce prawa handlowego, która jest właścicielem nieruchomości rolnej, reguluje natomiast art. 4 ust. 6 u.k.u.r. KOWR należy zawiadomić w każdym przypadku zbycia udziałów i akcji w spółkach handlowych, gdy podstawą nabycia jest nie tylko inna czynność prawna, ale także inne zdarzenie prawne, takie jak jednostronna czynność prawna, orzecze-

${ }^{28}$ Informacje uzyskane przez Krajowy Ośrodek stanowią tajemnicę przedsiębiorstwa w rozumieniu art. 11 ust. 4 ustawy z dnia 16.04.1993 r. o zwalczaniu nieuczciwej konkurencji (Dz.U. z 2018 r. poz. 419). 
nie sądu, organu administracji lub organu egzekucyjnego, dziedziczenia, zapisu windykacyjnego, podziału, przekształcenia lub łączenia spółek handlowych. $\mathrm{W}$ takim przypadku KOWR przysługuje prawo nabycia względem tych akcji i udziałów.

3.3. Dalsze ograniczenia w nabywaniu przez cudzoziemców udziałów (akcji) w spółkach prawa handlowego mogą wynikać z przepisów kodeksu spółek handlowych oraz umów lub statutów spółek. Problematyka ta jest niezwykle obszerna i w zasadzie wykracza poza tematykę artykułu. Należy jednak przynajmniej zasygnalizować, że chociaż prawo do swobodnego zbywania udziałów (akcji) jest jednym z podstawowych uprawnień wspólnika ${ }^{29}$, to przepisy kodeksu przewidują pewne ograniczenia w zbywaniu udziałów (akcji), stanowiące wyjątki od możliwości realizowania niniejszego prawa. W odniesieniu od spółki z o.o. wynikają one bezpośrednio z przepisów k.s.h. ${ }^{30}$ lub z umowy spółki (art. 182 §1 k.s.h.). Umowne ograniczenie w zbyciu może polegać m.in. na przyznaniu określonym podmiotom, najczęściej dotychczasowym wspólnikom, prawa pierwokupu udziałów. W takim przypadku należy uznać, że prawo pierwokupu Krajowego Ośrodka wyprzedza pierwokup podmiotu określonego w umowie spółki. Przepis art. 3a u.k.u.r. jest bowiem lex specialis w stosunku do art. 182 k.s.h.

W odniesieniu do akcji kwestię ograniczeń w obrocie, także w odniesieniu do cudzoziemców, reguluje art. 337 § 1 k.s.h. stanowiąc, że akcje mogą być przedmiotem obrotu. K.s.h. przewiduje ograniczenia w zbywaniu akcji imiennych wydawanych za wkłady niepieniężne (art. $336 \S 1$ k.s.h.) oraz akcji imiennych, do których przywiązany jest obowiązek powtarzających się świadczeń niepieniężnych (art. 356 § 1 k.s.h.). Ograniczenia w zbywaniu akcji imiennych może także przewidywać statut, $\mathrm{w}$ tym $\mathrm{m}$.in. może być to zakaz zbycia na rzecz określonych podmiotów lub prawo pierwokupu dotychczasowych akcjonariuszy. Także w odniesieniu do akcji uznać należy, że prawo pierwokupu Krajowego Ośrodka Wsparcia Rolnictwa wyprzedza pierwokup podmiotu określonego w statucie spółki.

4. Reasumując objęcie ograniczeniami ustawowymi nabywania udziałów i akcji w spółkach handlowych będących właścicielami lub użytkownikami wieczystymi nieruchomości rolnych nie zostało wystarczająco przemyślane, a przepisy regulujące tę problematykę są niespójne.

${ }^{29} \mathrm{~W}$ odniesieniu do spółki z o.o. wynika ono ex lege z art. 180 k.s.h.

${ }^{30}$ Art. 16, art. $181 \S 1$, art. $183 \S 1$ art. $176 \S 3$ k.s.h. 
W szczególności objęto zakresem działania u.k.u.r. przypadki nabycia udziałów i akcji, które w żaden sposób nie godzą w obrót nieruchomościami rolnymi. Wprowadzone do u.k.u.r. zmiany miały bowiem ma celu ,wzmocnienie ochrony ziemi rolniczej w Polsce przed jej spekulacyjnym wykupowaniem przez osoby krajowe i zagraniczne, które nie gwarantują zgodnego z interesem społecznym wykorzystania nabytej ziemi na cele rolnicze". Antyspekulacyjny cel ustawy, wprowadzony w szczególności z uwagi na cudzoziemców nabywających nieruchomości rolne lub udziały i akcje w spółkach prawa handlowego będących właścicielami nieruchomości rolnych w Polsce wydaje się nieproporcjonalną ingerencją KOWR, działającego na rzecz Skarbu Państwa, w działalność gospodarczą, także rolniczą działalność gospodarczą podmiotów prywatnych. Stanowi to nieuzasadnione wzmocnienie pozycji podmiotu państwowego (KOWR) względem podmiotów prywatnych, które prowadzą działalność w organizacyjnoprawnej formie spółki prawa handlowego. Uprawnienie z tytułu prawa pierwokupu dotyczy bowiem nie tytko spółek, które prowadzą działalność rolniczą, ale i takich, które tej działalności w ogóle nie prowadzą, a nieruchomości rolne stanowią nieistotny, marginalny składnik majątku.

Nadto na podstawie powołanych przepisów KOWR może stać się wspólnikiem (akcjonariuszem) spółki mimo braku woli ze strony pozostałych wspólników. Narusza to zasady k.s.k. i dobre obyczaje, bez dostatecznych podstaw do tak dalece idącej ingerencji w skład wspólników. Nie bez znaczenia jest także przyznanie KOWR prawa do zapoznania się z istotnymi dla spółki informacjami, co stawia tę instytucję w uprzywilejowanej - w sposób nieuzasadniony - pozycji wobec innych podmiotów. Narusza to zasady konkurencji na rynku, nie tylko rolnym. Ponadto może prowadzić to wzmocnienia pozycji innych podmiotów, w których KOWR jest jedynym wspólnikiem.

\section{ACQUISITION BY FOREIGNERS OF SHARES IN COMPANIES OWNING AGRICULTURAL REAL ESTATE}

\section{Summary}

The subject of this article is restrictions on the acquisition by foreigners of shares in companies that are owners (perpetual usufructuaries) of agricultural real estate under the Polish legal system. Poland, similarly to some other EU Member States, has restricted the freedom to trade in real estate and introduced control over this trade through the use of instruments from the private as well as public law sphere. The degree of interference by the Polish legislator in trading in shares of commercial companies has been assessed basing on the Act on the acquisition of real estate by foreigners and the Act on the shaping of the agricultural system. 


\title{
L'ACQUISTO DI AZIONI E QUOTE DA PARTE DI STRANIERI NELLE SOCIETÀ PROPRIETARIE DI IMMOBILI AGRICOLI
}

\begin{abstract}
Riassunto
L'oggetto dell'articolo riguarda le restrizioni, presenti nell'ordinamento giuridico polacco, all'acquisto di azioni e quote da parte di stranieri nelle società proprietarie di immobili agricoli (usufrutto perpetuo). La Polonia, come alcuni Paesi dell'UE, ha introdotto specifiche limitazioni alla compravendita degli immobili, ricorrendo sia agli strumenti di diritto privato sia a quelli di diritto pubblico nell'esercitarne il controllo. Il grado di ingerenza da parte del legislatore polacco nelle operazioni di acquisto e vendita di azioni e quote delle società commerciali è stato valutato dal punto di vista giuridico, sulla base della legge in materia di acquisto degli immobili da parte di stranieri e di quella sul regime agricolo.
\end{abstract}


